\title{
David as Warrior, Leader, and Poet in Medieval Hebrew Poetry of al-Andalus
}

Shmuel ha-Nagid's Self-Portrait as "The David of His Age"

\author{
Barbara Gryczan
}

1

\author{
Introduction: Socio-historical background of Shmuel ha-Nagid's \\ Literary Activity
}

Shmuel ha-Nagid (993-1056) was one of the most influential Jewish dignitaries and intellectuals of al-Andalus as well as a prominent figure of the social and cultural phenomenon known as the convivencia. ${ }^{1}$ The convivencia refers to a period of relative tolerance and harmonic coexistence of the three monotheistic cultures under the Muslim rule in the Iberian Peninsula during the Middle Ages. Scholars of Jewish studies conventionally call it "the Golden Age" to convey the idea of a period of remarkable, unprecedented flourishing of Jewish culture from the tenth to the mid-twelfth centuries. ${ }^{2}$

The unique historical and political circumstances of the time allowed the Iberian Jewish population to establish prosperous and stable communities, headed by influential, intellectual elites. Once the two powerful players in the game - the Muslim and the Christian empires - established relatively stable geographic boundaries and began, at least for a while, to strive for peace, a space for a third party emerged and thus Jewish contributions came to be valued by both sides. Given that the Jews, an ethnic and religious group deprived of state and land, were perceived both as a neutral party in the local conflicts and also as a group open to 'civilising' influences of the larger empires, Jews

1 The article was written within the framework of the NPRH grant (Uniwersalia 2.2) awarded to Dr. Marzena Zawanowska to conduct a study for the realization of the research project Hebrajska poezja ztotego wieku w al-Andalus. Antologia [The Hebrew Poetry of the Golden Age in al-Andalus. An Anthology] (2018-2023; No. 22H/18/0199/86).

2 The term was initially introduced by the nineteenth-century Jewish historians and was quickly popularised, thanks to the publication of Heinrich Graetz's monumental (eleven volumes) Geschichte der Juden. In his groundbreaking work, which comprises the first modern-day extensive edition and academic commentary to the poetic works of the period, Yefim (Hayim) Schirmann described the phenomenon as the "Spanish miracle." See Goitein, A Mediterranean Society, vol. 5, 425 .

(C) BARBARA GRYCZAN, 2021 | DOI:10.1163/9789004465978_007

This is an open access chapter distributed under the terms of the CC BY-NC 4.o liçenşse.ra Gryczan - 9789004465978 
were often entrusted with the role of mediator between Christian and Muslim and considered eligible for prominent positions as those who could exercise official functions. Jewish dignitaries were thus able to provide care and support to their own communities. Imitating the Muslim rulers, they extended patronage to numerous scientific and artistic endeavours. As a result, the Jewish courtly life flourished.

The development of Jewish society was naturally stimulated by the advancement of the Islamic civilisation, since the thriving Muslim culture at its peak was an evident inspiration for non-Muslims and as such it exercised influence on the communities residing within its borders. However, it has been recently demonstrated in numerous publications that the idealised, romanticised picture of the Golden Age as an era of true 'civilisation' based on reciprocal admiration and acceptance envisioned by the nineteenth-century historians, is in fact a fanciful utopia. ${ }^{3}$ In reality, while the Muslim authorities remained tolerant towards the Jews, especially as long as the Jewish presence was considered useful, this did not mean that they were accepting, let alone admiring, of the representatives of the minority culture. In addition, both sides firmly believed in their own moral and religious superiority and their intercultural relations remained strictly formal. ${ }^{4}$ No historical evidence exists of intermarriage between the communities or even common feasting; on the one hand, the Jews fiercely guarded their ethnic integrity by means of separating themselves as much as possible from the Gentiles; on the other hand, while in general maintaining an interest in the latest scholarly and artistic accomplishments of their non-Muslim subjects for the sake of their own cultural development, the Muslims seem to have paid little attention to the intellectual achievements of the Jews. Furthermore, the tolerance of the Muslim societies was characterised by its strict and easily strained boundaries. History proves that the political mood in Andalusia was volatile and that on occasion the Muslim crowd could express its violent opposition to the rise of non-Muslim officials. If they reached too high on the political ladder, the Jews were reminded of their place.

3 For a detailed inquiry into the history of the Jewish-Muslim relations in the times of convivencia, see, e.g., Frank (ed.), Jews of Medieval Islam; Cohen, Under Crescent and Cross; Perlmann "Medieval Polemics"; Scheindlin "Jews in Muslim Spain"; Wasserstein, "Jewish Elites in Al-Andalus"; idem, "Muslims and Golden Age."

4 An inestimable source of information on the life of Jewish communities in Andalusia is the Cairo Geniza. Among the preserved documents (dating from the ninth to the nineteenth centuries) are letters exchanged between the representatives of Jewish elites from around the Mediterranean basin. The monumental work of editing and publishing a significant amount of these fascinating materials was done by Shelomo Dov Goitein, in his monumental, six-volume Mediterranean Society. 
For instance, in 1066, in spite of the official position of the authorities on the matter, the mob murdered approximately 3000 Jews in the anti-Jewish riots in Granada, while in the early gos of the same century, the Jews were officially exiled from the city-state of Granada after it had been conquered by the Almoravids.

Nonetheless, decades before these events, in the very same city of Granada, Shmuel ha-Nagid - known in Islamic circles as Ismāîl b. Nağrīla - rose to power and prominence. His life story provides a rare example of the spectacular success and career advancement of a man who rose from humble origins to become the most powerful man after the king and a respected leader of the Andalusian Jewry. Working up the ranks of administrative functionaries, he gained influence in his 2os, having been nominated by Habūs, the Berber king of Granada, to the position of counsellor. In the year 1037, serving under Habüs' successor, Bādīs, ha-Nagid was appointed a vizier and the commander-in-chief of Bādīs' army. Consequently, he led Bādīs' troops in numerous campaigns until his death in 1056, which was most probably caused by battle injuries. Moreover, he was equally active as the head of the Jewish community. In 1027, he was granted the title of the nagid - the official leader of the Jewish community. The key to his success was his unequalled skill at diplomacy, which was undoubtedly the most praised among his many virtues. ${ }^{5}$

However, in addition to his role in political and social life ha-Nagid was also a prominent figure in Jewish culture. His scholarly interests covered many diverse areas such as rabbinical studies, Bible exegesis, and Hebrew linguistics. In addition, as a man of influence and wealth, he was a committed patron of the arts. However, most importantly for our current discussion, he was a talented poet - the foremost representative of the new literary style - the first to

5 Ross Brann cites the opinions of ha-Nagid's contemporaries and the subsequent generations to indicate how highly esteemed he was, not only among the Jews but also among Muslims who, surprisingly enough, were willing to treat him as an equal. See Brann, Power in the Portrayal, 38-39. In contrast, ha-Nagid's son, Yehosef, who succeeded his father in the office, was openly criticised for his hubris and conceit. ha-Nagid chose him to be his heir not only as a politician but also as a man of letters. At a young age, Yehosef copied his father's diwan preceding each of the poems with a word of explanation and introduction (most probably dictated by Shmuel himself, as the boy is believed to have had been eight years old at the time). As a grown man, he proved himself to be as successful a strategist as his father (he was the one to outline and initiate the construction of the impressive fortress bordering Grenada, known today as Alhambra). However, because of his arrogance, Yehosef failed to gain the trust of the Jewish community and equally evoked the hostility and malevolence of his Muslim associates and subordinates. Consequently, Yehosef was the victim to allegations of disloyalty (he was accused of having planned a usurpation of the throne) and was murdered in the riots of 1066. 
have implemented in his verse all the innovative features characteristic of the poetics of the Hebrew Golden Age.

\section{Linguistic Background of the Revival of Biblical Hebrew}

Hebrew language and literature underwent a spectacular and rapid development from the tenth to the eleventh centuries owing to, amongst other factors, the linguistic endeavours of ha-Nagid and his contemporaries. The revolution had already begun, earlier in the East, with the works of Saadya Gaon, a Jewish scholar from Egypt, active in Babylonia, who initiated a new kind of rabbinic studies, namely biblical exegesis enriched with complex theoretical, lexicographic, grammatical, and linguistic analyses of the Hebrew language as well as sophisticated literary and stylistic studies of its poetics. His endeavours paved the way for the emergence of a new, "refined" type of liturgical poetry that was more elaborate and clearly structured as well as linguistically closer to the biblical model.

Sacadya's pioneering works quickly spread, reaching Jewish communities around the Mediterranean basin. As a result, his new approach dominated much of the intellectual endeavour of Jewish scholars and thinkers of the time. ${ }^{6}$ In poetry, "the quest for biblical purity at any cost"7 soon became one of their main concerns. The linguistic analysis inspired and fostered by such a clear-cut aim, helped to shape a consistent vision of what the norm of the language employed in lyrical works should be. This development, in turn, led to a flourishing of poetry, characterised by the Hebrew poets striving to make a reality of both the new vision. ${ }^{8}$

6 Sacadya's grammatical works, although groundbreaking, were soon surpassed by his prominent followers. In the long list of linguists, grammarians, poets and philosophers of the time, the name of ha-Nagid should definitely be included along with names such as Dunash Ben Labrat (920-99o), Jehudah Hayyuj (ca. 945-ca. 1000), Jonah Ibn Janah (ca. 990-ca. 1050), Solomon Ibn Gabirol (ca. 1021-ca. 1058), Moses Ibn Ezra (ca. 106o-ca. 1139), Judah Halevi (1071/75-1141), Abraham Ibn Ezra (1092-1167), Joseph Qimhị (1105-1170), David Qimḥi (116o1235), to name just a few.

7 See Sáenz-Badillos, History of the Hebrew Language, 227.

8 Norman Roth describes this phenomenon as the "complete resurrection of Hebrew language from the oblivion, into which it had fallen." See Roth, "Hebrew Language," 322. It may be worth mentioning that it was the first successful revival of the Hebrew language. Much like the representatives of the Haskalah and the then-Zionist movement in the nineteenth and early twentieth centuries, the poets of the Golden Age aimed to restore the Hebrew language and its literary tradition. Even though they were not as successful as the Zionists were in enforcing Hebrew to replace all other languages in all forms of communication, when it came 
The revolutionary character of the works of the Golden-Age authors is also evident in their implementation of an entirely new (in the Jewish lyrical tradition) poetic style inspired by Arabic verse. The poems were bound by strict and elaborate Arabic prosodic rules regarding their form and metre, while their content was enriched by a whole range of new subjects.

The new metre was introduced into Hebrew literature by Dunash ben Labrat, a student of Sa'adya who arrived from Egypt and was the first to propagate the innovative poetic style that has persisted ever since in the works of all the famous poets of the era. These poets, just like their Arab counterparts, exhibited interest in a wide array of secular topics, producing love poems, eulogies, "poems of desire," "poems of wine," "poems of friendship" and "poems of war."

Still, it ought to be noted that Hebrew poetry, even though secularised and inspired by the Arab verse on the formal level, was written in a language exceptionally faithful to the biblical model and deeply submerged in the conceptual as well as the historical reality of the Jewish sacred Scriptures. This characteristic, in turn, allowed for the emergence of new sophisticated rhetorical devices such as the šibuṣ (pl. šibūṣ̆m), which involves drawing certain verses or phrases from the Bible and incorporating them into the (usually contextually different) environment of the poem, and remez (pl. rëmāzim), which literally denotes a "hint," and stands for an evocation of certain biblical situations in poems. ${ }^{10}$ Both these devices, markedly inspired by the biblical form (language) and content, were introduced to Hebrew poetry by the Jewish Andalusian authors and, with time, became the hallmarks of the poetry of the Golden Age.

It is instructive to quote Ross Brann's comment, which encapsulates the revolutionary use of tradition by the Hebrew poets of the time in contrast to the far more conservative approach to the same sources of the traditionalists. He says:

to the language itself, they were more successful in restoring the Biblical model. Prominent linguists themselves, they were able to reconstruct precisely not only the semantic layer of the language but also the whole of its syntactic structure, together with the complex verbal system. Such was not the case with the modern revival of Hebrew in which the biblical lexicon was incorporated into a syntactic model far closer to the Slavic than the Semitic pattern, adopted (to some extent probably unconsciously) from the native tongue of Eliezer Ben-Yehuda and other Ashkenazi Zionists responsible for the revival of the language. For more on this issue, see, e.g., Zuckermann, "New Vision."

The poetics, genres, themes, structure, and cultural background of the medieval Hebrew poetry have been given a great deal of scholarly attention. For the most recent fundamental studies, see, e.g., the works of Arie Schippers, Ezra Fleischer, Israel Levin, and Shulamit Elitzur.

10 For a broader and more detailed characteristic of these rhetorical devices, see, e.g., Pagis, Change and Tradition; Lowin, Arabic and Hebrew Love Poems. 
[...] traditionalists continued to decipher the meaning of Scripture as contemplated by the rabbis and to maintain the interpretations cited in the Talmud and Midrash as if little had changed. But Hebrew poets began to spin webs of figurative magic by manipulating and flexing the diction, figures and associations of the Bible in ever more imaginative ways. ${ }^{11}$

\section{The Dream of the Neo-Solomonic Kingdom in al-Andalus}

The secularisation of the language of the Scriptures, as well as of the longestablished Jewish poetic tradition of the piyyut, appears as a surprising and even improbable phenomenon. Shmuel ha-Nagid, who belonged to the early generation of the secular poets of al-Andalus, is definitely among those responsible for this development. In all likelihood, he was the first to fully embrace and comprehensively develop the idea of reviving the biblical language through literature. As the most successful medieval Jewish intellectual and the first to profit from the new, favourable cultural and economic conditions, he distanced his art from the recent diasporic literary heritage. Instead, he fought for the revival of Biblical Hebrew that engendered cultural and historical continuity between the original literary corpus of the Scriptures and his modern texts. Hence, by writing works in Hebrew, he did not wish to be simply a representative of the liturgical synagogue lore but rather to act as a contemporary representative the biblical tradition and history - both understood in their broadest possible sense.

Furthermore, while reading ha-Nagid's works, one can hardly resist the impression that he lived a dream of the "neo-Solomonic kingdom in Andalusia." ${ }^{12}$ His aim was to revive not only the biblical language but also the whole of the Hebrew culture (even though away from Ereș Israel). He envisioned a strong, self-aware and influential Jewish society that created its own history, a worthy successor to the biblical one. These bold ambitions are clearly reflected, among other things, in the poem "Back away from me now, my friend," which we will discuss below.

In this sense, the language of the Scriptures was no longer to be perceived as the holy tongue of divine revelation, to be used solely for sacral proposes. It was to become the living language of contemporary Jewish history again. In his war poems, ha-Nagid attempted to create chronicles documenting the events of his own time, akin to their biblical prototypes. Therefore, he wished to find

\footnotetext{
11 See Brann, Compunctious Poet, 23.

12 See Cole (trans.), Selected Poems of Shmuel Ha-Nagid, xxiii.
} 
a way to legitimise his self-proclaimed and close-to-blasphemous role as the direct successor of biblical authors. To achieve this goal, ha-Nagid divided his diwan into three major parts, namely Ben Mišlēe, Ben Tĕhillīm, and Ben Qōhelet. The titles are meant to suggest an obvious connection between his works and biblical poetry, traditionally attributed to David and Solomon. The titles may be understood as "After the Book of Proverbs," "After the Book of Psalms," and "After the Book of Ecclesiastes," yet they can also be translated, perhaps more in accord with the author's intention, as "The Small Book of Psalms," "The Small Book of Proverbs," and "The Small Book of Ecclesiastes," understood as continuations of the biblical books.

Moreover, ha-Nagid's ambition was to serve not only as a mere scribe - a faithful recorder of events - but also as the main protagonist in such works, much like King David or Solomon, someone exercising a legitimate influence on the Jewish history of his time. Aspiring to be the leader of a renewed Jewish society modelled after the biblical Kingdom was probably even more audacious an endeavour than the idea of commenting on the current historical events in the biblical manner. Therefore, ha-Nagid never slackened in his efforts to legitimise his role, using every opportunity to create either a direct or allusive connection between himself and selected biblical luminaries.

\section{Ha-Nagid's Self-portrait as “The David of His Age” in his Poem Back away from Me Now, My Friend}

This tendency of ha-Nagid finds its utmost expression in the war poem Back away from me now, my friend. The piece reports the events of the battle of Argona, where ha-Nagid fought as the chief of the defending army. In the poem, he overtly proclaims himself as "the David of his age." The text is constructed in the form of a dialogue, being a polemical poetic discussion between the writer and an anonymous sceptical and critical disputant. ${ }^{13}$

The poem comes from the second volume of ha-Nagid's diwān, entitled Ben Těhillìm, which according to Peter Cole is:

13 Ha-Nagid's ideas were met with criticism to which he was very sensitive as testified, e.g., by his partially preserved poetic discussion with Isaac Ibn Khalfun. Khalfun's poems of criticism did not survive but we can read Ha-Nagid's ardent respond (in Ben Těhillimm 174176) proceeded by his son's introduction in which the "quarrel" with Ibn Khalfun is being directly addressed. 
[...] perhaps the most original of the three, as it introduces to postbiblical Hebrew poetry the full range of Arabic subject matter, complete command of the new poetics, and an unforgettably personal cast to the biblical language of the verse. This combination of subject, tone, and impulse aligns ha-Nagid with the martial-lyric spirit of Second Samuel and the Davidic Psalms, an affiliation ha-Nagid makes explicit at several points. ${ }^{14}$

It can be best classified as a war poem and a boast poem - both characteristic of the Iberian poetical culture of the time but belonging to a much older genre in received Arabic culture, dating back as far as the pre-Islamic oral poetic tradition. In contrast to its genre, the language of the poem and its rhetoric are deeply rooted in the text of the Scriptures. The elaborate use of paraphrases and hidden quotations from the biblical texts reveals a hidden agenda - an additional layer to the straightforward boast. ha-Nagid manages to strengthen his message and legitimise his claims by linking them directly to the sacred text. Thus, the present-day historical content of the poem is densely interspersed with the elaborate network of šibusșim and rěmāzimm.

ha-Nagid used those devices to prove that it was his legacy to be both the leader of the Jewish community and the singer of God and announced himself the legitimate heir and direct descendant of Jeduthun and "the David of his age." The set of šibusșim employed for that purpose is far more complex and refined than it appears at first glance. Below, I attempt to deconstruct some of them to demonstrate how those sophisticated literary and linguistic tools convey the poet's ideological claims.

The poem begins with a paraphrase of the last verse of Psalm 39:

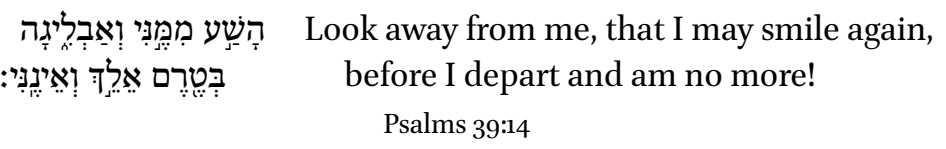

The above concluding verse of the psalm is a plea to God to refrain from judgement so that the supplicant can lead a peaceful life. Ha-Nagid uses the same phrase as an appeal to refrain from criticism; however, his invocation is not a humble request, but rather as part of a harsher repartee. Also, it is not directed to God but toward a sceptical human disputant:

Back away from me now, my friend

14 See Cole (trans.), Dream of the Poem, 38. 
It is, in fact, a warning, as revealed in the following section of the poem. His next verse also strongly evokes psalmic imagery:

Would you scare me with false accusations? ～What would I fear - with the Rock as my light and salvation?

The author proves his legitimacy by mentioning the divine support that he has been granted, just like the author of the Psalms. Let us look at some biblical verses from the Psalter that might have been inspirational for that line:

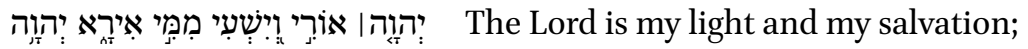

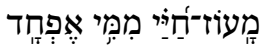
whom shall I fear?

Psalms 27:1

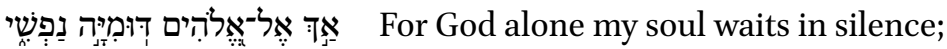

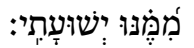
from him comes my salvation.

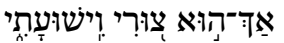
He alone is my rock and my salvation,

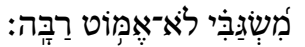
my fortress; I shall not be greatly shaken.

Psalms 62:2-3

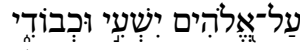

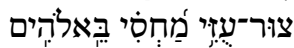

On God rests my salvation and my glory; my mighty rock, my refuge is God. Psalms 62:8

Having stressed that his status is equal to that of the Psalmist, ha-Nagid - who can with all certainty be identified with the speaker of the poem - continues his reproof. He warns his adversary that he will be treated as an enemy if he continues to discredit him or undermine the legitimacy of his claims:

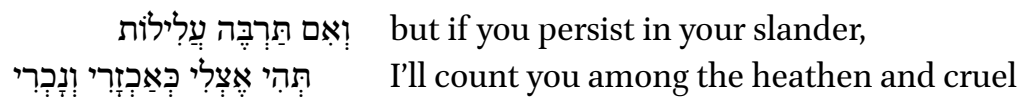

Moreover, in the following lines, the one who assaults his name is compared to the one who attacks his land:

\footnotetext{
No good could come of one who exalts himself over my family, no peace to him who threatens my city.
} 
Hence, the poet - soldier proves himself to be as serious and commited in his literal struggles as he is on the battlefield. What is more, while mentioning "his family," he indicates that he regards himself as a descendant of the Psalmist in particular, as well as the heir of the priestly and Levitical traditions in general. The attempt to prove such a connection must have been essential for ha-Nagid, as it is developed gradually throughout the whole poem in an elaborate manner.

In the next couple of verses, ha-Nagid describes his legacy more specifically, though not yet directly, as that of a descendant of the house of David - by the use of a sophisticated combination of a remez and a šibuṣ:

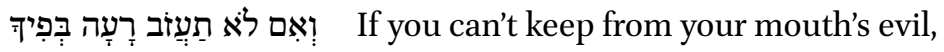

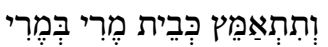
and insist on rebellion like Ezekiel's rebels then turn to me, friends, and listen,

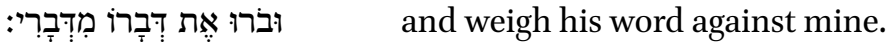

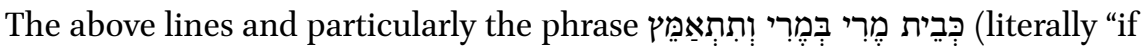
you persist to rebel like the rebellious house") correspond directly to chapter two of the Book of Ezekiel:

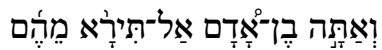

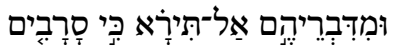

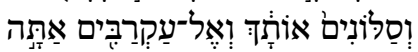

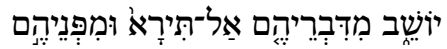

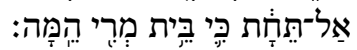

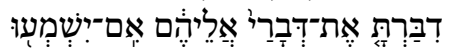

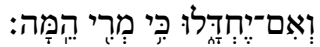

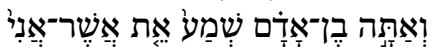

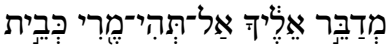

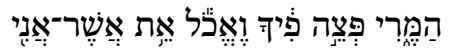

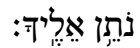

And you, son of man, be not afraid of them, nor be afraid of their words, though briers and thorns are with you and you sit on scorpions. Be not afraid of their words, nor be dismayed at their looks, for they are a rebellious house. And you shall speak my words to them, whether they hear or refuse to hear, for they are a rebellious house. "But you, son of man, hear what I say to you. Be not rebellious like that rebellious house; open your mouth and eat what I give you."

Eze 2:6-8

Ezekiel refers here to the rebellious nature of the house of Israel and speciaifcally to the events described in 2 Chronicles 13:1-22. ha-Nagid draws a connection between himself and the biblical prophet. He refers to the specific moment when Ezekiel, criticising his contemporaries, compares their deeds to those of Jeroboam and Belial, who rose against the authority of Rehoboam, the son of Solomon, even though the kingship over Israel was granted to David 
and his sons by God and ensured by the covenant. As they were "driven out the priests of the Lord, the sons of Aaron, and the Levites, and made priests for themselves like the peoples of other lands" (2 Chronicles 13:9), the followers of Jeroboam were challenged, rebuked, and defeated by Abijah, the king of Juda.

By quoting the words of Ezekiel where the prophet denounces "the rebellious house," ha-Nagid evokes the situation described in 2 Chronicles. Hence, with the use of just one phrase, he manages to link himself directly to the biblical prophet and priest (Heb. kōhēn) - Ezekiel - as well as the poet, military leader, and king - David. Moreover, just like Abijah and Ezekiel, ha-Nagid emphasises the importance of the role of the priests and Levites, who were also singers of psalms and poets, for the preservation of the Jewish identity. He insists on having his rightful place among them.

This stance may seem puzzling and surprising considering that he was a general of a Gentile army and a minister in a foreign government. Nonetheless, it was congruent with his vision of a renewed and prosperous Jewish society and not entirely unrealistic. As noted above, Jewish communities during the Golden Age experienced periods of remarkable success, even if occasionally interrupted by dramatic outbursts of violence. ha-Nagid's time was the period of the highest prosperity; life in his days was better for the diaspora than it had ever been before and was ever going to be afterwards. Fighting successfully to support the dominance of his protectors, ha-Nagid hoped to be able to ensure the well-being of his Jewish protégés and, from a longer perspective, eventually turn his neo-Solomonic utopia into reality.

To legitimise his actions, the poet, a couple of lines later, stresses once again that his choices are empowered by the "heritage" awarded to him by God. He strengthens these claims by again paraphrasing Psalm 62:

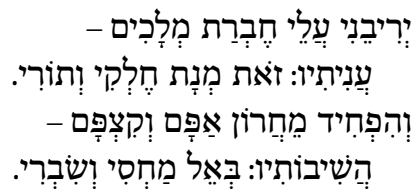

He disputes my alliance with kings.

This, I say, is my lot and inheritance.

He fears the face of their wrath.

My refuge and hope, I respond, is in God.

As the conversation with the imagined adversary continues, ha-Nagid is accused of recklessness for putting his life at stake in somebody else's war. $\mathrm{He}$ upholds the firm conviction that his actions are granted divine commendation and his fate is secured. He even mentions that he has been assured of this by God's angels (Seraphs) in a dream:

What are these battles to you? he asks. ） And I answer: The place of my death 


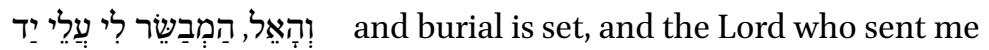

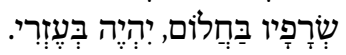
seraphs in a dream will save me.

Subsequently, ha-Nagid contemplates how people are predestined to their fate and adduces examples of vile biblical characters who, in peaceful times, were stricken by unexpected early death, such as the kings Zimri and Tivni or the Egyptian killed by Moses. Thus, he concludes no one can feel safe but the one who acts righteously and puts his trust in God. ha-Nagid is certain of his fate, knowing that he will live and die according to the divine plan. This statement together with his assumed priestly status is once again underlined by means of šibușìm from the Book of Psalms and a remez that alludes to the ceremony of the consecration of priests:

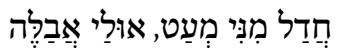

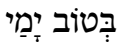

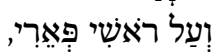

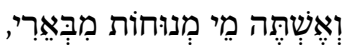

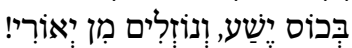

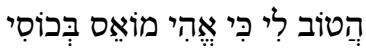

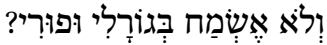

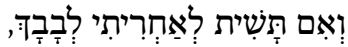

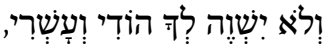

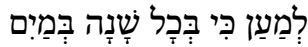

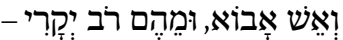

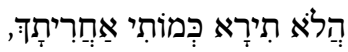

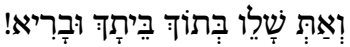

Leave off me now - maybe I'll spend my days in prosperity, a turban above me; I'll drink still water from my well in the cup of deliverance and running water drawn from my river. Is it right to despise my inheritance, and not rejoice in my portion and fate? If your heart hurts for my future, and refuses to fathom my wealth and splendour

because of the fire and water I come through year by year fear, my lord, for your own as for mine, though you're healthy at home, and calm.

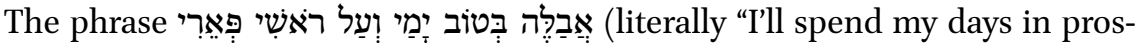
perity wearing a turban on my head") refers to the consecration ceremonies of Aaron and his sons described in Exodus 29 and Leviticus 8:

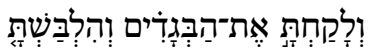

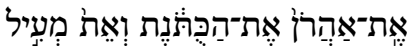

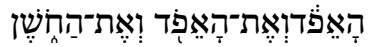

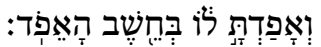

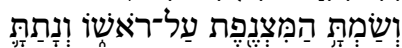

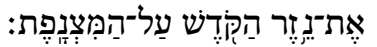

Then you shall take the garments, and put on Aaron the coat and the robe of the ephod, and the ephod, and the breastpiece, and gird him with the skillfully woven band of the ephod. And you shall set the turban on his head and put the holy crown on the turban.

Exodus 29:5-6 


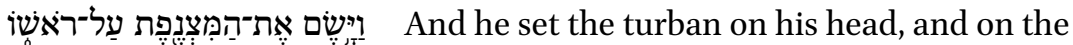

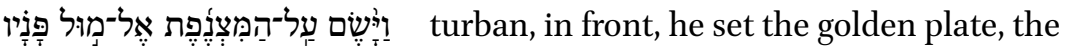

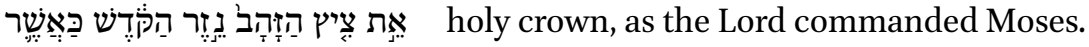

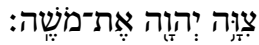
Leviticus 8:9

Mentioning the "turban on his head" - a symbol of priesthood - ha-Nagid makes a direct connection between himself and Aaron, the first anointed priest (kōhēn), and his house.

Into the next verse, the poet entwines phrases from Psalms 23:2 - מִי מְנוּחוֹת "still waters" - and Psalm 116:13 - כּסֹסישישוּעוֹת "the cup of salvation." Both are thanksgiving Psalms that convey gratitude for divine support and guidance. The popular Psalm 23 ("The Lord is my shepherd") expresses the joy of life and the sense of security enjoyed by those who follow God's path, while Psalm 116 articulates gratefulness to the Creator for preserving from peril - drinking from the cup of salvation is a thankful gesture of a survivor.

This last prayer, which is also a prayer of a saved warrior, brings us to the leading subject of ha-Nagid's poem, which is the recently won battle. A couple

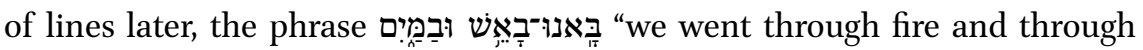
water" from Psalm 66:13 is paraphrased to "the fire and water I come through year by year," which serves again to validate ha-Nagid's engagement in war. In the following verse, he alludes to the Bible once more:

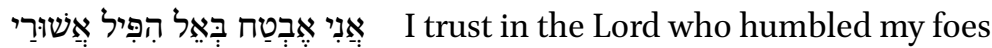

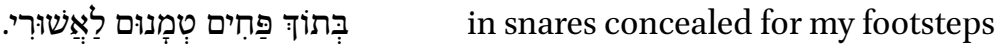

Here, Ha-Nagid compares himself to Jeremiah, another of the biblical priests and prophets of whom we read in the Bible:

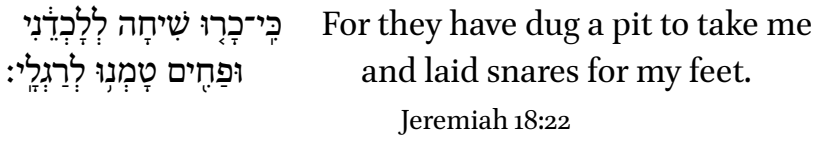

ha-Nagid might have felt especially connected to Jeremiah because the prophet was also criticised and plotted against by his contemporaries, a fact repeatedly mentioned in his book, as, for example, in chapter 18 , just a couple of lines before the above-cited verse: 


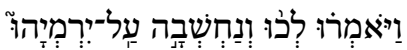

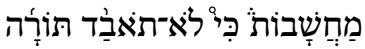

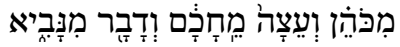

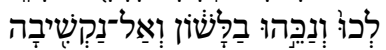

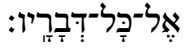

Then they said, "Come, let us make plots against Jeremiah, for the law shall not perish from the priest, nor counsel from the wise, nor the word from the prophet. Come, let us strike him with the tongue, and let us not pay attention to any of his words."

Jeremiah 18:18

After making all those claims and pointing out all the connections that serve to reaffirm his status as God's chosen leader and fighter, ha-Nagid moves to the description of the battle. The exact course of the battle is not of our concern here. However, worth noting is the manner in which it is reported. To ensure historical continuity with the events described in the Scriptures, ha-Nagid calls his enemies by the names of the biblical adversaries of Israel. Accordingly, the troops of the so-called "Slavs" (the non-Muslim mercenaries of European origin) are called Zemarites (i.e., Canaanite people who are mentioned in Genesis 10:18 and 1 Chronicles 1:16 as one of the "scattered clans"), while the two attacking "Spanish princes," Wāṣil and Muwāfaq, are compared to Og and Sihon (i.e., the Amorite kings who were defeated by Moses's army in Numbers 21, 32, and 33 and Deuteronomy 1, 2, and 3). Hence, thanks to this allusion, ha-Nagid places his achievements alongside the glorious victories described in the Torah and includes his name in the list of the leaders of the Jewish people, next to Moses.

In the closing stanzas, the poet addresses his interlocutor once again, expressing both his right and duty as a poet to praise God in thankful songs after complying with his obligation in the battle:

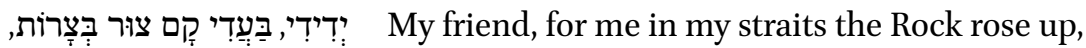

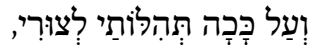

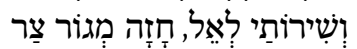

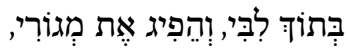

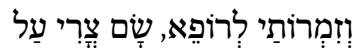

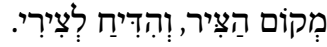
therefore I offer these praises, my poem to the Lord:

He recognized fear of the foe in my heart and erased it.

So my song is sung to the healer:

He ravaged my enemies with pain, easing my own.

That right is, however, questioned once again by the anonymous opponent:

Who are you to pay homage? 
The objection is refuted by ha-Nagid with the most explicit answer:

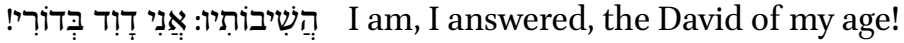

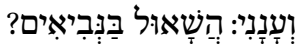
He responded: Is Saul, too, with the prophets?

And I told him:

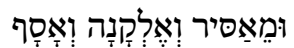

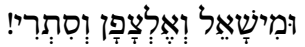

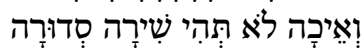

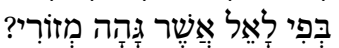

The heir of Merari, Sitri, and Assir,

Elkanah, Mishael, Elzaphan, and Assaf!

How could a poem in my mouth be improper

to the God who heals my wound?

In these concluding verses, ha-Nagid openly compares himself to King David and supports his claim with his alleged Levitic pedigree by adducing a list of names of Levi's offspring and contending to be their heir. His descent from these liturgical singers and poets provides an immediate justification for ha-Nagid's self-proclaimed status. As a Levite, he is not only granted the right to compose poetry in God's name but also even obliged to do so. Also, the Levitic provenance explains ha-Nagid's service under a foreign, non-Jewish king, as the Levites, being the servants of the Temple, were never granted their own land.

Moreover, in case the list of names was not considered credible enough, in the following lines, ha-Nagid declares himself to be a direct descendant of Jeduthun:

$$
\begin{aligned}
& \text { From Jeduthun the singer of psalms } \\
& \text { my father descends, }
\end{aligned}
$$

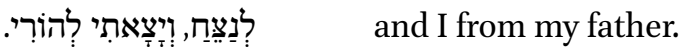

The poem opens with šibūșim from Psalms 39 and 62, both of which are attributed to Jeduthun, the singer of Psalms. As noted above, the first verse of the poem begins with a paraphrase of the last verse of Psalm 39. By quoting the words of Jeduthun at the outset of his lyrical work and mentioning his name at the end of it, ha-Nagid manages to craft an elaborate framing device, which reveals the most careful selection and deliberate choice of biblical materials.

In the closing lines of his poem, ha-Nagid openly and immodestly confesses to his covenant with God:

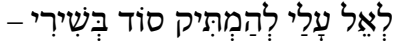

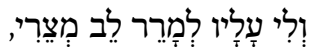

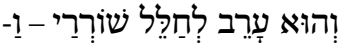

For the Lord I sweeten my song in its discourse, as He embitters my enemy's heart. As He has pledged to vanquish my foes, 


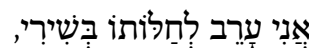

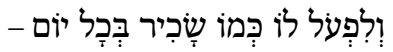

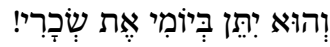

so I have pledged my song to please Him to worship Him day by day in my labor, until He pays my wage.

Hence, the poet maintains that he is anointed both as a poet and a warrior. God is pleased with his songs and thus favours him in the battle. Such an alliance accords ha-Nagid, at least in his view, the right to consider himself the "David of his age" and makes him feel invincible and tireless in building his dream of the kingdom. He is also hopeful of leaving that heritage to a successor who would live up to his monumental expectations. In another poem, also included in Ben Těhillīm, ha-Nagid declares:

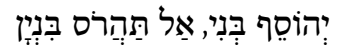

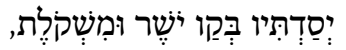

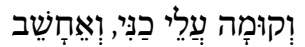

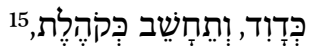

Yehosef my son, do not destroy a structure whose foundation I laid with the line and weight of integrity.

Assume my station, that I be taken

For David and you be considered Solomon. ${ }^{16}$

\section{Conclusions}

As we know ha-Nagid's neo-Solomonic dream was not to be fulfilled. His son and would-be-Solomon - Yehosef - was murdered in Granada in the bloody massacre of 1066. Afterwards no Jew in al-Andalus ever came again to assume a degree of power equal to that entrusted into the hands of Shmuel ha-Nagid.

However, the unique and prolific Hebrew culture thrived for another century in the Iberian Peninsula, leaving behind one of the most remarkable legacies of world literature. Shmuel ha-Nagid was not only among its pioneers, but also among its most prominent and original representatives - the only one to have composed war poems. Notably, as the only poet of all the medieval Jewish authors who was a soldier and a prince, he was bold enough to perceive himself, accordingly, as "the David of his age."

15 See Shmuel ha-Nagid, Ben Těhillìm, 64.

16 Translation after Ross Brann. See Brann, Compunctious Poet, 53-54. 


\section{Appendix: Ha-Nagid's Poem Back away from Me Now, My Friend}

Below, I present the Hebrew text of ha-Nagid's poem Back away from me now, my friend as edited by Dov Yarden (except for splitting the hemistichs and transferring the ceasura to the following verse in order to preserve the graphic correspondence between the Hebrew text and Peter Cole's English translation): ${ }^{17}$

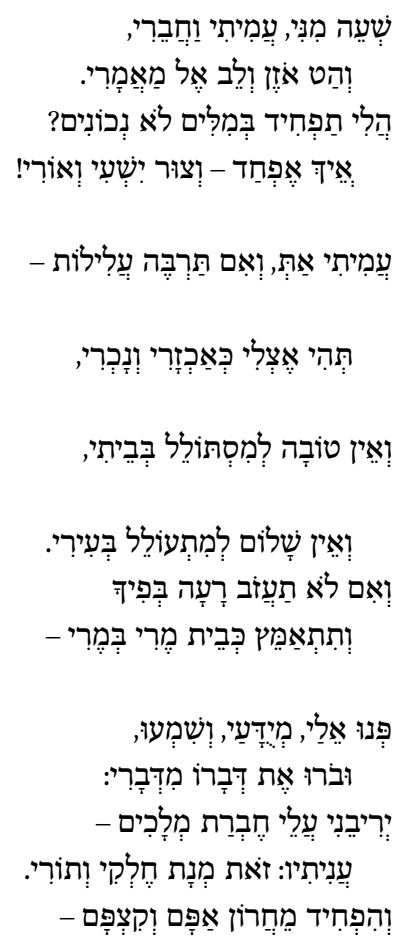

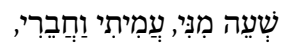

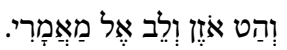

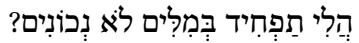

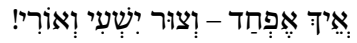

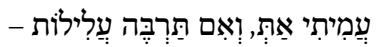

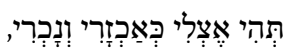

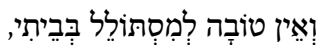

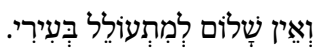

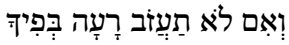

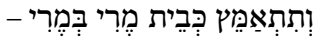

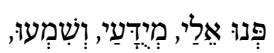

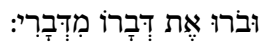

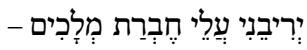

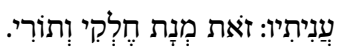

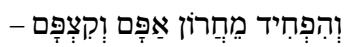

Back away from me now, my friend wait just a moment and hear my plan.

Would you scare me with false accusations? What would I fear - with the Rock as my light and salvation?

You've been in my circle, but if you persist in your slander,

I'll count you among the heathen and cruel.

No good could come of one who exalts himself over my family, no peace to him who threatens my city.

5 If you can't keep from your mouth's evil, and insist on rebellion, like Ezekiel's rebels -

then turn to me, friends, and listen, and weigh his word against mine.

He disputes my alliance with kings. This, I say, is my lot and inheritance.

He fears the face of their wrath.

17 See Shmuel Ha-Nagid, Ben Těhillīm, 31-34. English translation after Cole (trans.), Dream of the Poem, $5^{-}-53$. As in all the poems in the collection, it is headed by Yehosef's introduction which provides concise information on the background of this poem. It reads (in Cole's translation): "And Yaddayir the commander came to the place known as Argona in the year 4801 [1041], and with him were Waasil and Muwaafaq, both of them well-known officers among the Andalusian leaders, and they overcame Argona and killed the commander of the city. Afterward they marched to a place known as Samantin and overcame most of the castles there. And then our forces went out against them and the hand of God was with them and they killed Waasil and Muwaafaq. And Yaddayir fled until he was trapped at Cordoba and he was taken from there and imprisoned in the castle of Munekar. And my lord, my father, spoke of what happened to him and how he fared, praising God for having granted him this great victory." See Cole, The Dream of the Poem, 379. 


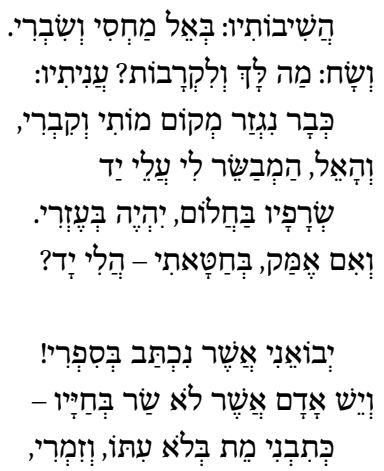

My refuge and hope, I respond, is in God. What are these battles to you? he asks.

And I answer: The place of my death and burial is set, and the Lord who sent me seraphs in a dream will save me.

If I were rotting away with sin could I stop it?

My book holds my destiny!

There are people who die before their time, like Zimri, who reigned for a week, or Tivni and others who face neither struggle nor war but are buried just like the Egyptian, whom Moses saw.

There are those who are swept away for want of righteousness,

and others in life who go hungry, poor and alone.

15 Leave off me now - maybe I'll spend my days in prosperity, a turban above me; I'll drink still water from my well in the cup of deliverance and running water drawn from my river.

Is it right to despise my inheritance and not rejoice in my portion and fate? If your heart hurts for my future, and refuses to fathom my wealth and splendour

because of the fire and water

I come through year by year,

20 fear, my lord, for your own as for mine, though you're healthy at home, and calm. I trust in the Lord who humbled my foes in snares concealed for my footsteps when the enemy came to the garrisoned city and slaughtered its vizier like a calf. He was a foe in the line of my king and the evil of strangers pales beside the evil of kin. 


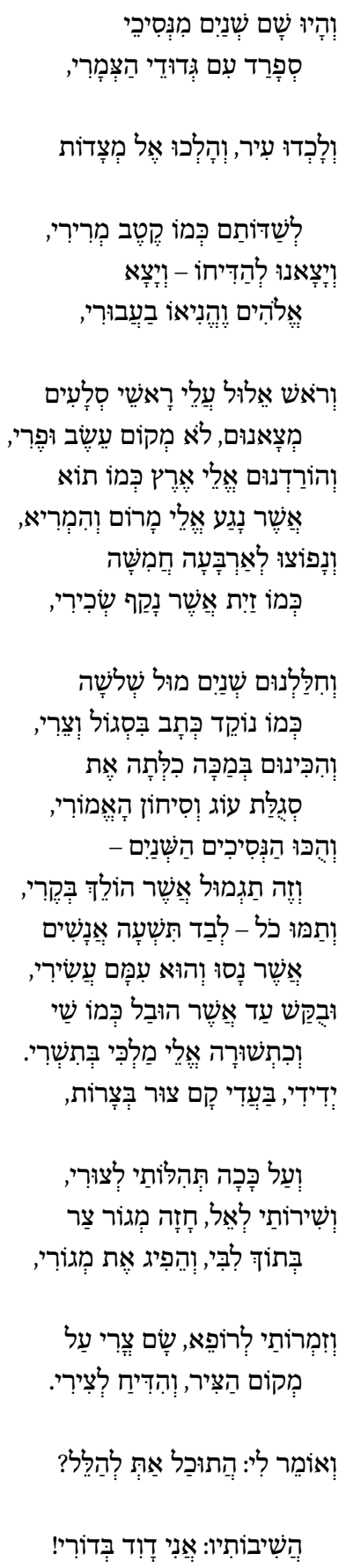

Two of the Spanish princes were there, and the Zemarite troops, and they seized the city,

25 then advanced like a pestilence,

destroying the fortress.

We went out to stop them, and He broke them before us, and August discovered their heads on stone,

not in the orchards and grass.

We brought them down to the ground like birds of the air who had raised their wings on high;

we chased them in clusters of four and five, like olives from a tree the worker has beaten.

We slew them two against three,

like long vowels against short in a word; we struck them the blow that had leveled the armies of $\mathrm{Og}$ and Sihon.

The princes were stricken, reward for their obstinance, and all of it ended, except for the nine who fled - their leader a tenth, pursued until he was brought like a gift, or tribute, that summer to my king. My friend, for me in my straits the Rock rose up, therefore I offer these praises, my poem to the Lord:

He recognized fear of the foe in my heart and erased it.

So my song is sung to the healer:

He ravaged my enemies with pain, easing my own.

Someone objected: Who are you to pay homage?

I am, I answered, the David of my age! 


\begin{tabular}{|c|c|c|}
\hline 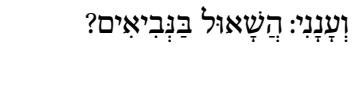 & & $\begin{array}{l}\text { He responded: Is Saul, too, with the } \\
\text { prophets? }\end{array}$ \\
\hline 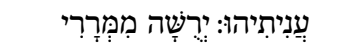 & & And I told him: \\
\hline וּמֵאַסִיר וְאֶלְקָנָה וְאָסָף & 40 & The heir of Merari, Sitri, and Assir, \\
\hline 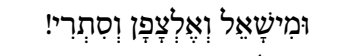 & & Elkanah, Mishael, Elzaphan, and Assaf! \\
\hline 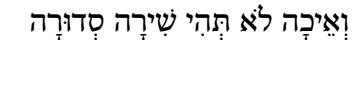 & & $\begin{array}{l}\text { How could a poem in my mouth be } \\
\text { improper }\end{array}$ \\
\hline 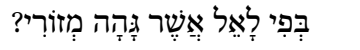 & & to the God who heals my wound? \\
\hline וּמֵהוֹרַי יְדוּתוּן הַמְהַלֵלל & & $\begin{array}{l}\text { From Jeduthun the singer of psalms } \\
\text { my father descends, }\end{array}$ \\
\hline 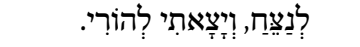 & & and I from my father. \\
\hline 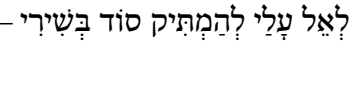 & & $\begin{array}{l}\text { For the Lord I sweeten my song in its } \\
\text { discourse, }\end{array}$ \\
\hline וְלִי עָלָיו לְמָרֵר לֵב מְצֵרִי, & & as He embitters my enemy's heart. \\
\hline 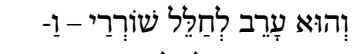 & & As He has pledged to vanquish my foes, \\
\hline אֲנְי עָרַב לְחַלוֹתוֹ בְּשְׁירִי, & & so I've pledged my song to please Him - \\
\hline 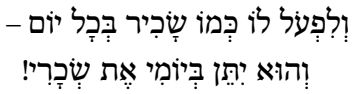 & 45 & $\begin{array}{l}\text { to worship Him day by day in my labor, } \\
\text { until He pays my wage. }\end{array}$ \\
\hline
\end{tabular}

\section{Bibliography}

\section{Primary Sources}

Biblia Hebraica Stuttgartensia. Stuttgard: Deutsche Bibelgesellschaft, 1997.

The English Standard Version Bible. Wheaton: Crossway Books, 2007.

ha-Nagid, Shmuel. Ben Mišlē. Diwan Shmuel ha-Nagid, edited by Dov Yarden. Jerusalem: Dov Yarden, 1982.

ha-Nagid, Shmuel. Ben Tĕhillim. Diwan Shmuel ha-Nagid, edited by Dov Yarden. 2nd edition. Jerusalem: Dov Yarden, 1982.

ha-Nagid, Shmuel. Ben Qōheleth. Diwan Shmuel ha-Nagid, edited by Dov Yarden. Jerusalem: Dov Yarden, 1992.

Sacadya Gaon. Kutub al-luga - Fragments. In "A Study of Inflection in Hebrew from Saadia Gaon's Grammatical Work Kutub al-Lughah," edited by Solomon Skoss. Jewish Quarterly Review, 33 (1942-43): 171-212.

\section{Secondary Literature}

Brann, Ross. The Compunctious Poet: Cultural Ambiguity and Hebrew Poetry in Muslim Spain. Baltimore: Johns Hopkins University Press, 1991.

Brann, Ross. Power in the Portrayal. Princeton, Oxford: Princeton University Press, 2009. 
Cohen, Mark R. Under Crescent and Cross: The Jews in the Middle Ages. Princeton: Princeton University Press, 1994.

Cole, Peter (trans.). Selected Poems of Shmuel HaNagid. Princeton: Princeton University Press, 1996.

Cole, Peter (trans.). Dream of the Poem. Hebrew Poetry from Muslim and Christian Spain, 950-1492. Princeton - Oxford: Princeton University Press, 2007.

Elitzur, Shulamit. Hebrew Poetry in Spain in the Middle Ages. 3 vols. [in Hebrew]. Tel Aviv: The Open University of Israel, 2004.

Fleischer, Ezra. Hebrew Liturgical Poetry in the Middle [in Hebrew]. Jerusalem: Keter, 1975.

Fleischer, Ezra. Hebrew Poetry in Spain and Communities Under Its Influence. 3 vols. [in Hebrew]. Jerusalem: Ben Zvi Institut, 2010.

Frank, Daniel H. (ed.). The Jews of Medieval Islam: Community, Society, and Identity: Proceedings of an International Conference Held by the Institute of Jewish Studies, University College London, 1992. Leiden - New York - Koln: Brill, 1995.

Goitein, Shelomo, Dov. A Mediterranean Society, The Jewish Communities of the Arab World as Portrayed in the Documents of the Cairo Geniza. 6 vols. Berkeley - Los Angeles: University of California Press, 1967-93.

Graetz, Heinrich (ed.). Geschichte der Juden von den ältesten Zeiten bis auf die Gegenwart. 11 vols. Leipzig: Leiner, $1853-75$.

Halkin, Hillel. Yehuda Halevi. New York: Schocken, 2010.

Levin, Israel. The Embroidered Coat: The Genres of Hebrew Secular Poetry in Spain. [in Hebrew]. Tel Aviv: Katz Research Institute for Hebrew Literature Tel Aviv University, 1994.

Lowin, Shari L. Arabic and Hebrew Love Poems in al-Andalus. New York: Routledge, 2014.

Malter, Henry. Saadia Gaon: His life and works. Morris Loeb Series. Philadelphia: Jewish Publication Society of America, 1921.

Mamman, Aharon. Comparative Semitic Philology in the Middle Ages. From Sa'adiyah Gaon to Ibn Barūn (1oth-12th c.). Leiden - Boston: Brill, 2004.

Menocal, Maria Rosa, Scheindlin, Raymond P., Sells, Michael (eds.). The Literature of Al-Andalus (The Cambridge History of Arabic Literature). Boston - New York London: Little, Brown and Company, 2002.

Pagis, Dan. Change and Tradition in the Secular Poetry: Spain and Italy [in Hebrew]. Jerusalem: Keter, 1976.

Perlmann, Moshe. "The Medieval Polemics between Islam and Judaism." In Religion in a Religious Age, edited by Shelomo Dov Goitein. Cambridge: Association for Jewish Studies, 1974.

Roth, Norman. "Hebrew Language." In Medieval Jewish Civilization: An Encyclopedia, 322-29. New York - London: Routledge, 2003. 
Sáenz-Badillos, Angel. A History of the Hebrew Language, translated into English by John Elwolde. Cambridge: Cambridge University Press, 1996.

Scheindlin, Raymond P. Wine, Women and Death: Medieval Hebrew Poems on the Good Life. Oxford: Oxford University Press, 1986.

Scheindlin, Raymond P. The Gazelle: Medieval Hebrew Poems on God, Israel, and the Soul. New York, Oxford: Oxford University Press, 1991.

Scheindlin, Raymond P. “The Jews in Muslim Spain.” In The Legacy of Muslim Spain, edited by Salma Khadra Jayyusi. Leiden: Brill, 1992.

Schippers, Arie. Spanish-Hebrew Poetry and the Arabic Literary Tradition: Arabic Themes in Hebrew Andalusian Poetry. Leiden: Brill, 1994.

Schirmann, Yefim (Hayim). The History of Hebrew Poetry in Christian Spain and Southern France edited, supplemented, and annotated by Ezra Fleischer [in Hebrew]. Jerusalem: Magnes, 1997.

Simon, Uriel. Four Approaches to the Book of Psalms: From Saadia Gaon to Abraham Ibn Ezra. Albany, NY: State University of New York Press, 1991.

Wasserstein, David J. "Samuel Ibn Naghrīla ha-Nagid and Islamic Historiography in al-Andalus." Al-Qanțara, 14 (1993), 109-125.

Wasserstein, David J. "Jewish Elites in Al-Andalus." In The Jews of Medieval Islam: Community, Society, and Identity, edited by Daniel H. Frank, 101-110. Leiden: Brill, 1995.

Wasserstein, David J. "The Muslims and the Golden Age of the Jews in al-Andalus." Israel Oriental Studies, 17 (1997), 179-96.

Zuckermann, Ghilad. “A New Vision for 'Israeli Hebrew': Theoretical and Practical Implications of Analysing Israel's Main Language as a Semi-Engineered SemitoEuropean Hybrid Language." Journal of Modern Jewish Studies, 5(1) (2006), 57-71. 